\title{
MANAGEMENT FROM AN EDUCATIONAL PERSPECTIVE
}

\author{
Cornelia PETRE (STAN) ${ }^{a^{*}, \text { Loredana Elena COMĂNESCU }}{ }^{b}$, Nicușor DIACONU $^{c}$ \\ ${ }^{a b c}$ Valahia University of Târgovişte, Romania
}

\begin{abstract}
Authentic educational management supports and stimulates, by all possible means, the process of organization and functioning of educational organizations, in their essence, referring to the content, structure, process, which naturally involves the decentralization of educational management, of all its hierarchical structures, the efficient applicability of methods, techniques and tools, as well as the approach of modern managerial practices.

These involve the organization of educational structures, the promotion of school autonomy with all its advantages, together with the positive effects arising from these actions of major importance, which work together to ensure access conditions and school success- a fundamental objective of educational management, from the whole system to the school level.

The general managerial objectives at the level of both global and local educational system, of the school itself, correlate, one by one, with the new orientations and realities appropriate to a democratic and open society, with the directions of the education reform. They are organically linked to the value system and express the perspective of the development of education, values that ensure socio-human progress.

The objectives of the paper are the analysis of educational management and its impact on schools and the identification of appropriate managerial procedures in order to increase educational performance. The research include the ways in which the quality of the managerial act contribute to improving the satisfaction of the direct beneficiaries of the instructive-educational process, regarding the acquisition of new skills. These beneficiaries are students.
\end{abstract}

KEYWORDS: education, leadership, school, society.

DOI: 10.24818/IMC/2021/02.09

\section{INTRODUCTION}

The coordination of human resources, as part of management, is in charge for carrying out three principale types of activities: leadership, with a pronounced creative character, consulting activities and operational activities. Although human resources management is generally the main function of a specialized department, it can be stated that this activity is extrapolated outside it. Mainly, the general responsibility lies with the senior management, the leader, the manager. The president of a company / institution coordinates the work environment. He has the power to appoint the Vice President for Human Resources and other important coordinators.

Management is settled by people. In the purpose to fulfill the personnel function of the organization, the director and his collaborators from the human resources department should act according to the maximum performance standards, but also applying the ethical norms of their profession. The activity focuses on establishing those skills, techniques, information whose influence on the performance of each employee and the company is fundamental.

\footnotetext{
* Corresponding author. E-mail address: stancornelia1984@yahoo.com
} 
The social environment is constantly changing, which is why leadership has become an internal requirement for any organization / public institution but also an external requirement of the environment in which the organization / public institution operates.

The etymological root of the notion of ethics is in Greek: ethos, and the notion of morality has its roots in Latin: mores.

Ethics represents the domain that study moral principles, with their laws of historical development, with their class content and their scope in social life. Also, ethics is the sum of the norms of moral conduct matching to the ideology of a certain class or society.

So, according to the first tradition of defining ethics, it is considered: the science of behavior, morals; theoretical study of the principles that govern practical problems, and morality is considered: the totality of the means we use to live in a humane way; the set of concrete prescriptions adopted by individual or collective agents. According to the second tradition of definition, ethics includes a set of rules of conduct shared by a specific community, rules which are based on the separation between good and bad.

\section{MANAGEMENT MODELS AND EDUCATIONAL LEADEARSHIP}

\subsection{Considerations regarding educational leadership}

Friedman and Lotan observed four causes of mental exhaustion for teachers: equal relationships between teachers and students, equal relationships between teachers and their family, equal relationships between the teachers and social and organizational environment, and teachers' perception of their role. The last aspect refers to the attitude towards the support of the management and I consider, at the level of the impact of the managerial style / managerial leadership style as it is manifested. This is one of the factors of mental exhaustion among teachers globally and in Israel in particular. The degree of functioning of the teacher depends especially on the manager, who functions as a leader with a certain style, who should initiate innovative ideas so that each teacher feels that the institution in which he teaches as a specific part of his life. The meaning of "mission" is the basis of any success. If a teacher feels responsible for the success of students, he will be involved. A happy teacher will also make his students happy. Leadership has changed over the last years regarding methods and theories. Educational leadership requires the tolerance and patience of those responsible. The most important contribution of long-term leadership is to help and protect people and organizations to develop. One of the important objectives of the research was the development of a prediction tool for teacher satisfaction as a mirror and reflection of the manager's administrative leadership style. The innovation of the model proposed in this study consists in exploring for the first time the ability to predict the systemic role of teachers in a defined managerial environment. Using the dimension of absenteeism as a prediction factor is a process of evaluating future events by positioning existing information in a predetermined way.The fundamental reasons for the instrument derive from the studies we have conducted, from which it can be deduced that the dimension of absenteeism is the most significant component that indicates the level of teacher satisfaction. The emotions of the manager reffering to his role and the role of teachers will influence their functioning. His role in a modern school is based on his task orientation due to the variety and multitude of demands and needs of the society as a multicultural one. A manager should plan, measure, evaluate, manage and supervise, and in the same time, support his students as well as his teachers in pedagogical, social and organizational tasks. Normally, involvement in multiple tasks affects the manager's perception of his role and his way of managing staff.

His managerial style will influence the satisfaction among teachers, which in time will affect the role in different dimensions. It is also important for school managers to have mutual professional, social and moral support. "If you want something done, measure it. If you can't define it, you can't measure it. If you can't measure it, you can't manage it. You can't improve it. " (Barro \& Lee, 2019, 
p.26) Teachers' satisfaction is a relevant factor in Israel and globally. It is focused on beliefs, behaviors and emotions. This is an indicator of the worker's feelings about the job. It could be a tool used in order to predict behaviours, such as the degree of employee contribution to the workplace, the level of absenteeism and even for predicting abandonment. The employee's commitment to the job is associated with the employee's satisfaction with his or her job. There are many definitions for the concept of teacher job satisfaction.

One of them is a positive attitude towards work, which is manifested by the desire to stay in their field of work. Herzberg (1966) was one of the key figures in satisfaction research. He defines it as a positive attitude of the employee towards his job, which is manifested in his desire to stay there. From this, it can be concluded that there is a link between job satisfaction and a recommendation of that place to a friend.

Some authors link satisfaction to the school atmosphere. When the school atmosphere is usually influenced and measured by managerial style and is involve in decision-making, teachers' work and their perception of the system and when managerial style is based on trust, personal example, staff compensation and openness it enjoys more satisfaction. For a manager who has responsibility for decision making, guidance and direction, creativity is an essential factor in generating a positive organizational atmosphere (Friedman et al., 1988). It can be assumed that the more developed the organizational climate of the school, the higher the level of satisfaction among teachers. (Barro \& Lee, 2019, p.24).

The notion of management includes a pragmatic action content, it refers to the actions, functions or processes through which the objectives of an organization are achieved. However, as the effective exercise of these actions and functions requires a set of special knowledge and skills, researchers in the field have concluded that management belongs to the field of arts. Thus, Servan-Schrieber stated that art is the most creative art "the art of the arts, because it intends to direct the talents of others". (Servan - Schrieber, 1967, p. 3).

Recommendations for managers:

1. Recommendations for ways to increase employee / teacher satisfaction

2. Recommendations for ways to increase the role and commitment of teachers in the system The degree of functioning of the teacher depends on a manager whose style allows him to initiate creative ideas that will make each teacher feel that the institution is an essential part of the teacher's life.

A sense of mission is the basis for every success. When a teacher feels a personal responsibility for the success of his students, he will not be absent. A happy teacher will contribute to his students' happiness. The concept of leadership is changing permanently. The most relevant long-term contribution is a leader who protects and develops people, institutions and organizations. (Barro \& Lee, 2019, p.25)

\subsection{Roles and competencies specific to school management}

According to the Dictionary of Pedagogy, the school management or the school organization represents the global-optimal-strategic management activity of the education / training activity designed and realized within the basic unit of the education system: kindergarten, primary school, gymnasium school, vocational school, high school, college, college. It turns out that school managers are those people who exercise roles, responsibilities and competencies. (Cohen \& Soto, 2017, p.44)

According to H. Mintzberg, managers would always play a set of roles, through which they should express managerial skills, as presented in table 1. 
Table 1. Managerial roles and skills

\begin{tabular}{|l|l|}
\hline ROLE & MANAGEMENT SKILLS \\
\hline $\begin{array}{l}\text { 1. Interpersonal roles } \\
\text { Lentral figure } \\
\text { Contact person }\end{array}$ & $\begin{array}{l}\text { Due to the formal authority and the status of } \\
\text { superiors, managers have to make very good } \\
\text { interpersonal contacts with subordinates, peers } \\
\text { and managers at higher levels. }\end{array}$ \\
\hline $\begin{array}{l}\text { 2. Informational roles } \\
\text { Monitor }\end{array}$ & $\begin{array}{l}\text { They are extremely important in managerial } \\
\text { activity, in data collection, organization and } \\
\text { dissemination. }\end{array}$ \\
$\begin{array}{l}\text { Snformation node } \\
\text { Spokesman }\end{array}$ & $\begin{array}{l}\text { 3. Decision-making roles } \\
\begin{array}{l}\text { Entrepreneur - designs and initiates changes } \\
\text { in the organization. } \\
\text { Resource allocator - decides who, when and } \\
\text { what kind of resources he receives. } \\
\text { Negotiator - participates in negotiations on } \\
\text { behalf of the organization, ensuring that its } \\
\text { interests are well defended. } \\
\text { Corrector - decides what course certain } \\
\text { actions can take in unusual situations. }\end{array}\end{array}$ \\
\hline
\end{tabular}

Depending on the hierarchical level at which the attributions of school managers are exercised, the profile and the size of the school organization, the roles are manifested in specific forms. However, their most important roles could be identified: decision maker, organizer, evaluator, mediator. These roles in turn involve concrete tasks, as follows. (Cohen \& Soto, 2017, p.44)

The coordinating director, in his capacity as state representative in the public or private school institution, ensures the transposition into practice of the line of educational policy elaborated at central (M.E.C.) and territorial level (school inspectorate). For this, he is concerned with: applying the legislative norms included in the official texts (laws, decrees, ordinances, orders, circulars, instructions); rational capitalization of real and potential pedagogical resources, establishing the optimal functioning organizational chart; animation and psycho-pedagogical and social counseling of the team; taking on special human resources options ("tell me how to do the job and I'll tell you what kind of director you are"); perfecting decisions in terms of their effects.

We can appreciate, in agreement with Dragomir M. and collaborators, that the main objective of the principal is to provide skill and experience in the field of education, so as to obtain optimal and safe performance, using the most appropriate methods. The principal must show maximum interest in the field of school management and knowledge about it, so that he can establish and achieve, in summary, two categories of objectives:

1. strategic objectives - long-term, which take into account the organization and planning of school activity;

2. operational objectives of a tactical and administrative nature - which have in view the direction of the activity aiming at the daily management of the work teams.

- The deputy principal, responsible for the activity of improvement and didactic research, has in view the stimulation of innovation at the level of the school organization, in relation to the existing resources. For this purpose, it aims at: perfecting the pedagogical projects on the background of 
emphasizing the formative objectives; flexibility of pedagogical messages, at the level of successive efficient communication operations; institutionalization of amelioration experiments. (Cohen \& Soto, 2017, p.46)

- The deputy director, responsible for the orientation and methodological guidance of the educational process directs his activity in the following directions: institutionalization of evaluation tools (observation sheet, analysis-synthesis sheet, opinion questionnaires, control grid); practicing them in conditions of rigor specific to the school inspection norms; evaluation of teachers' progress through specialized school inspection activities, carried out in collaboration with the head of the department / methodical commission, in accordance with a certain schedule of inter-attendances established at managerial level; improving the dialogue and communication with the evaluated one; evaluating the quality of relationships between teachers and students, teachers and the local educational community; capitalizing on the results in the direction of continuous teacher training.

- The deputy principal responsible for administrative issues aims at the efficient planning and organization of the existing pedagogical resources (human, material, financial, informational) respecting the educational policy lines established at the level of the entire management of the school institution.

\section{Table 2. Comparative dimensions of efficient and inefficient school management}

- optimal use of resources (human, material, financial, etc.)

- the ability to motivate staff, to direct them towards objectives and to organize them according to their skills

- good horizontal and vertical communication

- current, objective and stimulating evaluations for all staff

- rational collaboration with partners

- correct delegation of the attributions of subordinates

- use of modern management techniques (consulting, computer systems for data storage, stimulating the creativity of subordinates)
- mismanagement of resources (human, material, financial, etc.)

- tense organizational climate

- blockages in communication

- incompatibility between collaborators, between staff and responsibilities

- unpredictable situations, problems that were not anticipated and hinder the activity

- manager overcrowding (his involvement in too many problems)

- lack of collaboration with partners (manager "knows everything")

- exaggerated managerial style (either too authoritarian or too democratic)

- wrong assumption of responsibility (the manager either assumes the responsibility of others or does not even assume his own responsibility)

- involvement of subordinates in activities other than those specific to the job 


\section{EDUCATIONAL MANAGEMENT IN THE FRAMEWORK "BOGDAN PETRICEICU HAȘDEU" SCHOOL}

\subsection{Description of the organization}

Documentarily attested since 1987 that the "Spiru Haret" Primary School from the Tatarasi neighborhood (Corp B), on September 1, 2005, 108 years have passed since the establishment of the general school no. 22 Iasi, which became the "Bogdan Petriceicu Hașdeu" School after 1990, a name under which the school has asserted itself and has established itself in all these years as one of the most important and respected school units of Iasi primary and secondary education.

The school "Bogdan Petriceicu Hașdeu" (Corp A) has been operating since December 1, 1968. Starting with the school year 2004-2005, the school B. P. Haşdeu "became the coordinating school, taking over the schools" Costache Negri "and" Costache Conachi "which became bodies C and D. The latter has been operating since 1946. Later, body E was put into use, at the beginning of the school year 2007- 2008. Also within the "Bogdan Petriceicu Hașdeu" school, there are 6 SAM classes within the UCECOM School Group, Iași.

\subsection{Structure}

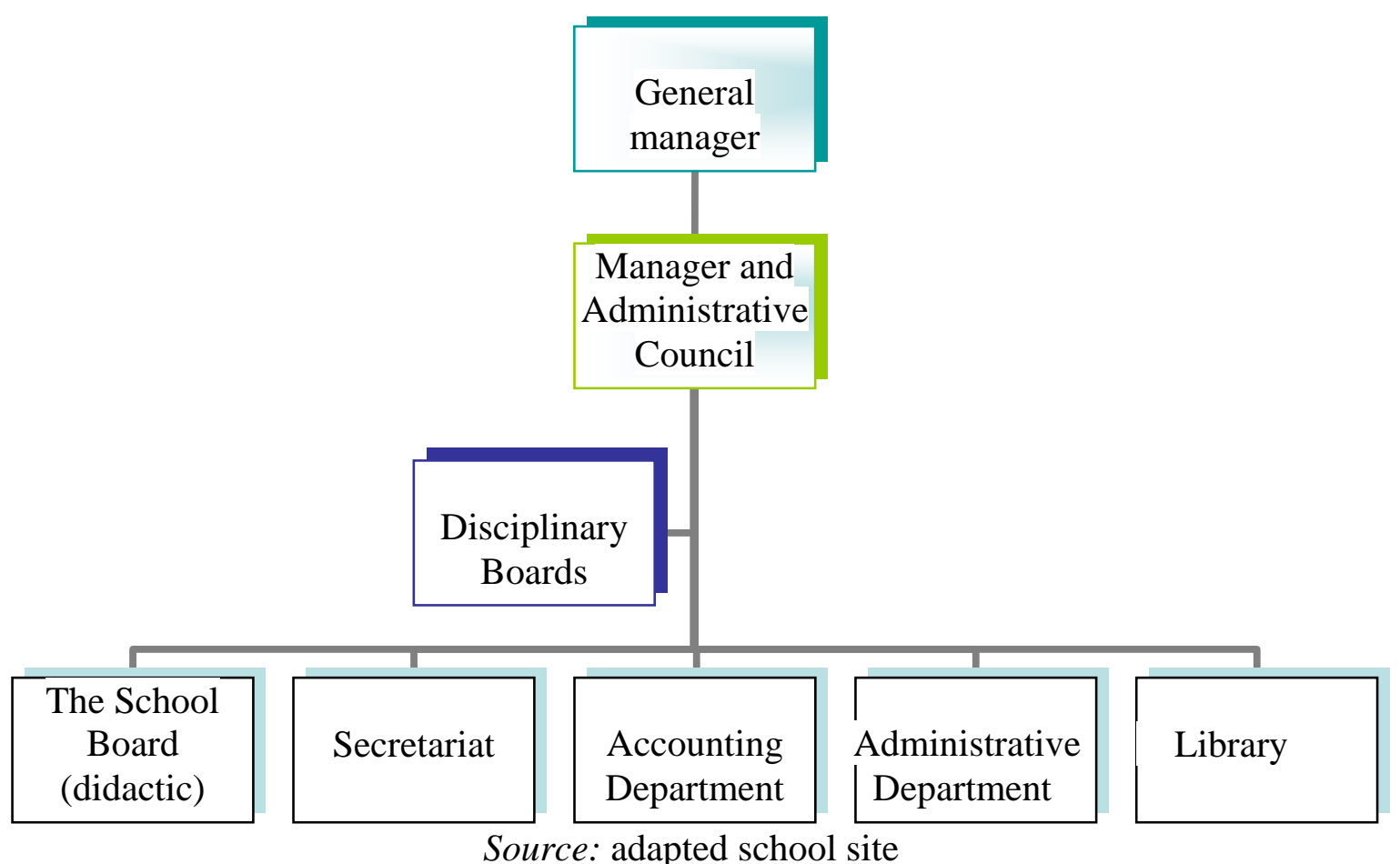

\subsection{Identifying and defining the problem, respectively its connections with other problems within the organization}

- lack of parental involvement in supporting and supporting students in the preparation of lessons, homework on various subjects, as they have become more busy and more concerned with their work in the country or abroad to earn money;

- the decrease of the students' motivation for the school activity and the appearance among them of some deviant behaviors: violent acts, lack of respect towards colleagues, teachers, lack of school, adherence to a street group, indiscipline in classes;

- lack of educational activities in the free time of students;

- loss of control over the child is lost on the part of the parents or persons in whose care the children remain. 
The causes / opportunities that led to the problem

- the departure of the parents to work abroad;

- parents are too busy at work or have multiple activities that take up their time to pay attention to their children;

- low motivation of students for learning, because they find activities that seem more important to them, such as: computer, television, etc .;

- the child's adherence to a street group;

- lack of educational, cultural, intellectual activities in the child's free time that may occur and for financial reasons, parents can not support or accompany children to such activities;

- relatives (especially grandparents) do not have the ability to guide students for school work and to follow them permanently;

- non-supervision of children.

Formulation of the objectives to be achieved by solving the problem (SMART)

$\checkmark$ creating its own framework for carrying out students' leisure activities;

$\checkmark$ mitigation of negative behaviors among students, indiscipline, school dropout, violence, etc .;

$\checkmark$ maintaining a family-student-school collaboration for the benefit of the student;

$\checkmark$ raising the level of preparation of students.

\subsection{SWOT analysis relative to the analyzed problem}

\section{Strenghts:}

- the school is located in a less polluted area, without dangers;

- the existence of specialists with experience among the school (psychologists, psychopedagogical teachers);

- the existence in the school of a space that could be used by students for leisure activities;

- the pass rate is $99 \%$;

- almost all the graduates of this school go to high school and continue their studies at the faculties;

- collaboration agreements are concluded between the school and the detained associations, foundations, associate professors who teach optional subjects;

- the proven capacity of a work team to submit a project in order to obtain MEC funding.

\section{Weaknesses:}

- low interest from teachers for unpaid activities;

- material and financial difficulties among the students' families and the impossibility to support some free time activities;

- inappropriate behavior of some students, implicitly the negative influence of colleagues.

\section{Oportunities:}

- development of MEC funded programs;

- accepting the project of setting up a home for children with special needs (whose parents are abroad or who do not care who to entrust);

- the financial contribution of the tutors to achieve this goal;

- the availability of specialists to get involved in carrying out activities and educating children;

- affirmation by participating in competitions and Olympics at national level;

- attracting as many funds as possible for carrying out the educational activity in conditions. 


\section{Threats:}

- the possibility that some children give up along the way;

- the lack of interest of the specialists, because they attract other more advantageous offers.

\subsection{Identifying, arguing and presenting the optimal solution. Elaboration of implementation} scenarios and solving possible difficulties / objections

School after school

- the project obtained MEC funding;

- contract with the "Pro Activ" Association, which manages the range of activities;

- complex activities that respond to several requests;

- partnerships for optional activities;

- the endowments (equipment, furniture, etc.) remain with the school at the end of the project;

- parents know that students are safe, prepare homework, have optional activities and meals until they leave work, better alternatives than hiring a person to take care of the child until the parents return.

\subsection{Ways to evaluate / verify the achievement of objectives}

- questionnaires for students and parents;

- the situation at school;

- issuing a statement regarding the number of deviations from the school regulations, class, number of indiscipline acts, etc :;

- concluding a collaboration contract with the parents;

- parent committee

\subsection{Research results}

How was the research carried out?

Over a five-month period in 2017, data were collected from survey participants through two complementary research methods.

Participants were asked to complete a questionnaire during their participation. This data was returned by the end of the week of their program.

Another method refers to a study in which participants offered to take part. The survey allowed the research team to understand the high-level trends that emerged from the classroom study.

\section{Who participated in the research?}

\section{a. Study in the classroom}

The first study on leadership power concentrated on high-level trends and it has been completed by 20 participants in a leadership development program within the "Bogdan Petriceicu Hasdeu" School. Participants were a men (73\%), within the ages of 36 and $50(68 \%)$ and they were representitive senior or middle management at the executive level $(64 \%)$.

Table 3. Gender analysis

\begin{tabular}{|lcc|}
\hline Gender & Percentage in class & Post Program Percentage \\
\hline Male & $73 \%$ & $64 \%$ \\
\hline Female & $24 \%$ & $36 \%$ \\
\hline Unidentified & $3 \%$ & \\
\hline
\end{tabular}

Source: adapted from Barro, R. J. (2018, p.41) 
Table 4. Analysis according to age

\begin{tabular}{|lcc|}
\hline Age & Percentage in class & Post Program Percentage \\
\hline $26-30$ & $1 \%$ & $2 \%$ \\
\hline $31-35$ & $8 \%$ & $9 \%$ \\
\hline $36-40$ & $19 \%$ & $25 \%$ \\
\hline $41-45$ & $24 \%$ & $25 \%$ \\
\hline $46-50$ & $25 \%$ & $20 \%$ \\
\hline $51-55$ & $14 \%$ & $11 \%$ \\
\hline $56-60$ & $8 \%$ & $8 \%$ \\
\hline $61+$ & $1 \%$ & \\
\hline
\end{tabular}

Source: adapted from Barro, R. J. (2018, p.40)

\section{b. Post Program Study}

About two weeks after the program carried out by the "Bogdan Petriceicu Hasdeu" School, 45 participants who received an online survey that asked qualitative questions about leadership and power. Participants were in majority male (64\%), aged between 36 and 50 (70\%), at the executive level (43\%).

Table 5. Analysis according to the level occupied within the "Bogdan Petriceicu Hasdeu" School

\begin{tabular}{|ccc|}
\hline Demography: Level in the Organization & Percentage in class & Post Program Percentage \\
\hline First level & $1 \%$ & $2 \%$ \\
\hline Middle management & $17 \%$ & $30 \%$ \\
\hline Upper middle management & $28 \%$ & $16 \%$ \\
\hline The principal & $36 \%$ & $43 \%$ \\
\hline Top managers & $15 \%$ & $9 \%$ \\
\hline Unidentified & $3 \%$ & \\
\hline
\end{tabular}

Source: adapted from Barro, R. J. (2018, p.39)

c. Leadership and power

Researchers investigated if the managers of the "Bogdan Petriceicu Hasdeu" School have the perception of their sense of power.

The tendency was to become stronger managers within the "Bogdan Petriceicu Hasdeu" School. One of the question of the survey was: How strong do you think you are at work? Survey participants were asked to rate how strong they feel at work on a scale of 1 to 7 where 1 equals "Not at all strong" and 7 equals "extremely strong." 
The researchers wanted to understand how is considered power within the "Bogdan Petriceicu Hasdeu" School. The answers indicate some tensions. Most of the respondents (59\%) consider that the mayor's office is in support of their citizens at all levels, and 53\% of those interviewed agreed that the "Bogdan Petriceicu Hasdeu" School rewards leaders for the well-being of the people. A percentage of $55 \%$ of respondents stated that power is concentrated in a small number of individuals selected in the "Bogdan Petriceicu Hasdeu" School. 28\% of the questionnaire interwied agreed that power is being abused by top leaders in the Bogdan Petriceicu Hasdeu School.

Only 29\% believe the school instructs leaders on how to use leverage effectively. The "Bogdan Petriceicu Hasdeu" school also rewards the leaders who empower the people they lead, thus encouraging the responsibility of the employee as a whole; there are few organizations which teach leaders how to effectively use the power they have. Participants were asked if they agreed with a series of statements regarding the exercise of power in the "Bogdan Petriceicu Hasdeu" School.

Table 6. Analysis according to the power level exercised

\begin{tabular}{|lc|}
\hline Percentage of agreement & $59 \%$ \\
\hline My school empowers people at all levels. & \\
\hline In my school, the power is concentrated in the hands of a few selected people. $55 \%$ & $53 \%$ \\
\hline The school rewards leaders for empowering their people. & $29 \%$ \\
\hline My organization teaches leaders how to leverage their power. & $28 \%$ \\
\hline Power is being misused by the top leaders in my organization. & \\
\hline
\end{tabular}

Source: adapted from Barro, R. J. (2018, p.41)

\section{CONCLUSIONS}

The role of human resources management is to maintain the functionality of the company's conditions in order to achieve the target performance quota and to ensure the efficient use of human resources. During the activity there are certain factors, among which the external conditions, the organizational conditions, the characteristics of the staff. An obligatory condition for achieving the targeted performance and efficiency in the organization is the elaboration of human resources strategies, which intervene directly in the process.

Human Resources includes all aspects of employee management, respective recruitment, employment, training, retention and dismissal. For each specific area, there are human resource management strategies. Because employees are such a useful resource in any organization, successful human resource management techniques are needed to create a productive team environment that will generate profitable business for the company.

Management involves "obtaining and combining different categories of resources necessary to achieve organizational goals". (Longenecker, Pringle, 1981, p. 54). The realization of a modern, flexible and efficient education system is a major objective of any society because the level of professional training of the human factor is decisive in obtaining a higher productivity and competitiveness. (Storey, in Hall D.T, 1986, p. 3). The main role of the managers in the educational sector is to solve the problems and challenges that appear in the organizational environment of each school unit. What is wanted in the public sector are those people able to promote institutional adaptations in the public interest. 
Top-management plays an integral role among the management resources at an institution, along with recruitment and selection, training and development, managerial performance, public service ethics and others. The transition from the information-based society to the globalized society, based on knowledge, self-knowledge and lifelong learning, is achieved through periods of transition, periods that (Meryem Le Saget 1999, pp. 12-15) characterizes and synthesizes in five complementary directions. but systemically and coherently constituted.

The implementation of the strategy affects a top-down organization, as well as all areas of operation and all departments of the business. In order to develop, organizations need to create structures capable of anticipating, with a small margin of error, trends in social evolution in general, as well as structural and content changes in the market in particular. European training and education systems need to adapt both to the requirements of the knowledge society and to the needs of the desire to improve the quality of employment. They must provide opportunities for education and training for all target groups at different times in life: young people, adults, the unemployed and people whose occupations are affected by their low skills.

The European Union promotes cooperation between Member States, supports and complements their action in certain areas of education and training, in accordance with the principle of subsidiarity, promoting quality by generating "European added value". The European Union, by virtue of its competence to support, contributes to the development of project management in the field of education through the normative regulatory dimension of the set of programmed actions as well as through the execution dimension of the programs established and implemented in order to achieve the European objectives.

Supporting the field of education is a priority objective of European Union policy, being assisted by implementation programs and funds planned for the implementation of actions in the field of education through European projects.

The issues presented in the paper on education are of significant importance, as they aim to support the development, transfer and / or implementation of innovative practices, as well as the implementation of joint initiatives for promotion, cooperation, peer learning and exchange of experience at European level, in order to make available to all those involved in the educational act (teachers, students, community), a high-performance, efficient instructive-educational process, correlated with the requirements of modern society.

\section{REFERENCES}

Barro, R. J., \& Lee, J.-W. (2018). ,International Comparisons of Educational Attainment, National Bureau of Economic Research, Working Paper No.4349, Cambridge, MA.

Barro, R. J., \&| Lee, J.-W. (2019). International Measures of Schooling Years and Schooling Quality. American Economic Review, 86 (2), 218-223.

Barro, R. J., \& Lee, J.-W. (2019). International Data on Educational Attainment: Updates and Implications. Oxford Economic Papers. 53(3), 541-563.

Becker, G. S. (2018). „Capitalul uman: o analiză teoretică şi empirică cu referire specială la educație", Editura ALL, București.

Becker, G. S. (2020). Investment in Human Capital: A Theoretical Analysis. Journal of Political Economy, 70(5), Part 2: Investment in Human Beings (October), 9-49.

Cohen, D., \& Soto, M. (2017). Growth and Human Capital: Good Data, Good Results. Development Centre Technical Papers No.179, OECD.

Gooderl Longenecker, J., \& Pringle, C. (1981). Management, C. E. Merrill.

Le Saget, M. (1999). Managerul intuitiv: o nouă forță, Trad. de drd. Carmen Lucreția Dinu. Economica, București.

Pearce, J. A., \& Robinson, R. B. (2010). Comparative Strategy, Irwin, Boston.

Servan-Schreiber, É. (1967). Bibliothèque nationale de France, Retrieved October1, 2016.

Storey, in Hall D. T. (1986). Career Development in Organizations, Cengage, Boston USA. 